\title{
Verbalpartikelvariation i de germanske sprog
}

\section{Sten Vikner}

I have two goals in this paper, namely (1) a more global one: to present (and try to account for) the variation concerning verb particles across the Germanic languages, and (2) a more "local" one: to use some of this variation data to support my analysis that Yiddish is an SOV-language like German and Dutch and not an SVO-language like English and the Scandinavian languages. Yiddish is similar to German as far as verb particles are concerned, and this follows from an analysis of Yiddish as SOV, but not from a hypothetical SVO-analysis.

Nøgleord: verbalpartikler, præpositioner, sammensatte verber, SVO, SOV, præpositionel passiv, dansk, engelsk, tysk, jiddisch

\section{Indledning}

Jeg har to mål i denne artikel, nemlig:

- $\quad$ et mere globalt mål: at give et overblik over variationen i verbalpartikler på tværs af de germanske sprog (se fx Haiden 2005, McIntyre 2007 og mange andre), og

- $\quad$ et mere lokalt mål: at bruge data fra denne variation til at underbygge min påstand om at jiddisch er et SOV-sprog ligesom tysk og nederlandsk, og ikke et SVO-sprog som engelsk og de skandinaviske sprog.

Alle germanske sprog har både løse og faste verbalpartikler (på engelsk hedder de 'separable' og 'non-separable', på tysk 'trennbar' og 'nicht trennbar'). Her er eksempler fra dansk, engelsk og tysk: 
(1a) Kontrakten udløb i $2013 . \quad$ FAST

(1b) Vandet løb ud på gulvet. $\quad$ LØS

(2a) The patient underwent an operation. $\quad$ FAST

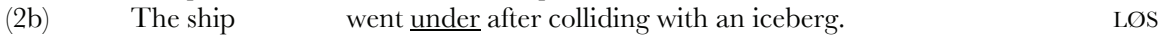

(3a) Das Auto umfährt den Pfosten. (= 'Bilen kører rundt om stolpen') FAST

(3b) Das Auto fährt den Pfosten um. (= 'Bilen vælter stolpen') LØs Bilen (om-)korer palen $\quad \overline{(o m)}$

Forskellen mellem løse og faste verbalpartikler svarer således helt til den forskel man ofte finder i den dansksprogede faglitteratur mellem 'fast sammensatte verber' (som i (1a)) og 'løst sammensatte verber' (som i (1b)).

\section{Løse verbalpartikler}

\subsection{Forskellen mellem prapositioner og (løse) verbalpartik- ler $i$ engelsk}

En forskel mellem præpositioner $\left(\mathrm{P}^{\circ}\right)$ og $($ løse $)$ verbalpartikler $\left(\operatorname{Prt}^{\circ}\right)$ i engelsk er at en præposition altid står foran sit DP-komplement, hvorimod en verbalpartikel enten kan stå foran eller efter DP'en:

(4a) I accidentally stepped on the radio.

$\mathrm{P}^{\circ}$

(4b) * I accidentally stepped the radio on.

(5a) I accidentally switched on the radio.

$\operatorname{Prt}^{\circ}$

(5b) I accidentally switched the radio on.

Haegeman \& Guéron (1999: 250-254) nævner følgende andre forskelle:

1. Sammen kan $\mathrm{P}^{\circ}+\mathrm{DP} h v$-flyttes, det kan $\operatorname{Prt}^{\circ}+\mathrm{DP}$ ikke:

(6a) In which hotel did the Beatles stay __?

(6b) * $\underline{\underline{I n}} \underline{\text { which }} \underline{\text { door }}$ did the Stones kick —? $\quad \mathrm{Prt}^{\circ}$

2. Sammen kan $\mathrm{P}^{\circ}+\mathrm{DP}$ kløves, det kan $\operatorname{Prt}^{\circ}+\mathrm{DP}$ ikke:

(7a) It was in this hotel that the Beatles stayed _..

(7b) * It was in this door that the Stones kicked —. . $\quad \mathrm{Prt}^{\circ}$ 
3. $\mathrm{P}^{\circ}+\mathrm{DP}$ kan koordineres med en anden $\left[\mathrm{P}^{\circ}+\mathrm{DP}\right]$, hvorimod $\mathrm{Prt}^{\circ}+\mathrm{DP}$ ikke kan koordineres med en anden $\mathrm{Prt}^{\circ}+\mathrm{DP}$ :

(8a) He looked up the chimney and down the stairwell. $\underline{\underline{T}}$. $\quad \mathrm{P}^{\circ}$

(8b) * She switched off the TV and on the light. $\underline{\text { PV }}$

4. $\mathrm{P}^{\circ}+\mathrm{DP}$ kan modificeres, fx af right eller straight, men det kan $\operatorname{Prt}^{\circ}+\mathrm{DP}$ ikke:

(9a) The Beatles stayed right in this hotel. $\quad \mathrm{P}^{\circ}$

(9b) * The Stones kicked $\underline{\text { right } \underline{\text { in this } \underline{\text { door}} .}}$ Prt $^{\circ}$

Til sidst noget om ellipse, dvs. udeladelse af en konstituent som allerede er forekommet en gang. Verbet selv kan kun elideres ved $\mathrm{P}^{\circ}$, og ikke ved en $\mathrm{Prt}^{\circ}$ :

(10a) He looked up the chimney and she looked down the stairwell.

$\mathrm{P}^{\circ}$

(10b) He looked up the chimney and she down the stairwell.

(11a) He switched off the TV and she switched on the light.

(11b) * He switched off the TV and she ___ on the light.

$\operatorname{Prt}^{\circ}$

På den anden side kan kombinationen $\mathrm{V}^{\circ}+\mathrm{Prt}^{\circ}$ elideres, hvorimod $\mathrm{V}^{\circ}+\mathrm{P}^{\circ}$ ikke kan:

(12a) He looked up the chimney and she looked up the stairwell.

$\mathrm{P}^{\circ}$

(12b) * He looked up the chimney and she the stairwell.

(13a) He switched off the TV and she switched off the light.

(13b) He switched off the TV and she the light.

\subsection{Verber og partikler i de germanske SVO-sprog}

Analysen af eksemplerne med præpositioner er relativt uproblematisk, nemlig som i (14a):

(14)

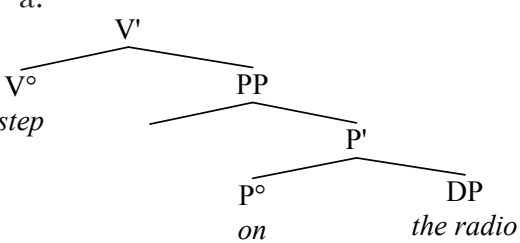

b.

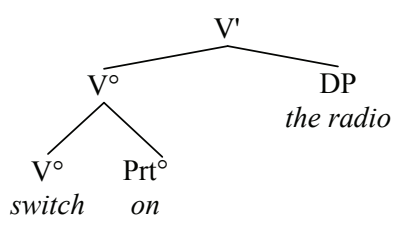


Analysen af partikel-eksemplerne er til gengæld ikke helt ligetil. Tag fx "the single verb hypothesis", som illustreret i (14b) ovenfor. Forskellen mellem (14a) og (14b) ville kunne forklare følgende:

- $\quad$ I (14a) udgør $\mathrm{P}^{\circ}+\mathrm{DP}$ en konstituent $\left[\mathrm{P}^{\circ}+\mathrm{DP}\right]$, nemlig en $\mathrm{PP}$, og derfor kan $\left[\mathrm{P}^{\circ}+\mathrm{DP}\right]$ hv-flyttes, (6a), kløves, (7a), koordineres, (8a), og modificeres, (9a). Verbet alene kan udelades, (10b), det udgør en konstituent, men verbum og præposition kan ikke udelades sammen, (12b), idet de ikke udgør en konstituent.

- $\quad \mathrm{I}(14 \mathrm{~b}) \mathrm{udg} ø r \mathrm{Prt}^{\circ}+\mathrm{DP}$ ikke en konstituent, hvorfor Prt $^{\circ}+\mathrm{DP}$ ikke kan $h v$-flyttes, (6b), kløves, (7b), eller koordineres, (8b). Grunden til at man ikke kan modificere i (9b) er at man ikke kan intervenere i det verbum som udgøres af verbum og partikel sammen. Verbum og partikel kan udelades sammen i (13b), idet de udgør en konstituent.

Grunden til at verbet ikke kan elideres alene i et partikel-eksempel som (11b) kunne være at man ikke kan elidere en del af et verbum, og verbet switched $\mathrm{i}$ (11b) udgør ifølge (14b) en del af det sammensatte verbum switched on.

Så vidt, så godt, hvad angår "the single verb hypothesis" i (14b) (se også McIntyre 2013 for et forsvar for denne analyse). Der er dog også mindst tre problemer:

Det første problem er at hvis $\mathrm{V}^{\circ}+\mathrm{Prt}^{\circ}$ udgør et verbum, så ville man ikke forvente at partiklen kunne topikaliseres, men det kan den, både i svensk og $\mathrm{i}$ dansk (faktisk ville alle danske eksempler med partikler og objekter være problematiske fordi objektet forekommer mellem $\mathrm{V}^{\circ}$ og $\operatorname{Prt}^{\circ}$, se $\mathrm{fx}(23)$ nedenfor):

$$
\begin{aligned}
& \text { Herstedvester har ladet Magnus sidde på bænken efter det gule kort og } \\
& \text { ind har de sat Emre. }
\end{aligned}
$$

http://ekstrabladet.dk/skolefodbold/nyheder/sjaellandmidt/article4596398.ece

Det andet problem er at hvis $\mathrm{V}^{\circ}+\mathrm{Prt}^{\circ}$ udgør et verbum, så ville man forvente at fleksionsendelserne ville forekomme ved dette verbums højrekant. Det er dog ikke tilfældet, idet fleksionsendelserne forekommer midt i "verbet": 
(17a) * He [switch-onned] the radio this morning.
$(17 \mathrm{~b}) \quad$ He [switched on] the radio this morning.
(18a) * He [switch-ons $]$ the radio every morning.
(18b) He [switches on] the radio every morning.

Det tredje problem er at hvis $\mathrm{V}^{\circ}+\mathrm{Prt}^{\circ}$ udgør en morfologisk enhed, så ville man forvente at dette element ville have samme kategori (m.v.) som dens højre datter, ligesom tilfældet er i andre komposita: dark-room er et substantiv ligesom room (den højre datter), ikke et adjektiv som dark, og tax-free er et adjektiv som free (den højre datter), ikke et substantiv som tax. (To) switch on er derimod ikke en partikel som den højre datter on, men et verbum, som den venstre datter, switch. Med andre ord, hvis $\mathrm{V}^{\circ}+\operatorname{Prt}^{\circ}$ udgør et verbum, så overtræder det det som Williams (1981: 248) kalder "the Right Hand Head Rule".

Derfor foreslår Haegeman \& Guéron (1999: 257-258) at partikelkonstruktioner som i (19a) har en basisstruktur helt parallel til eksemplerne med præpositioner (altså at partikler og præpositioner er forskellige varianter af samme ordklasse, jf. at mange partikler og præpositioner er helt ens):

a.

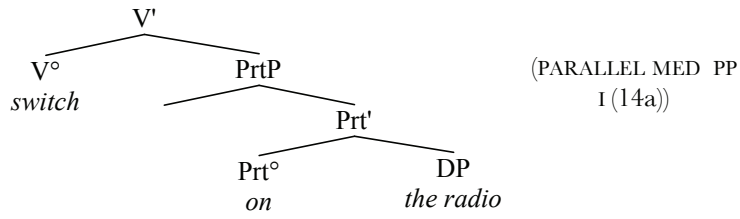

b.

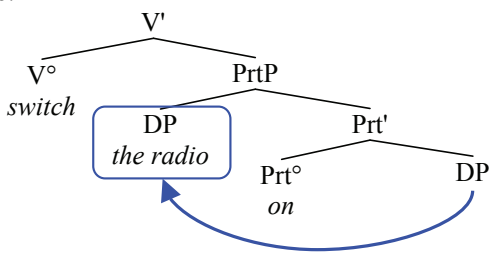

c.

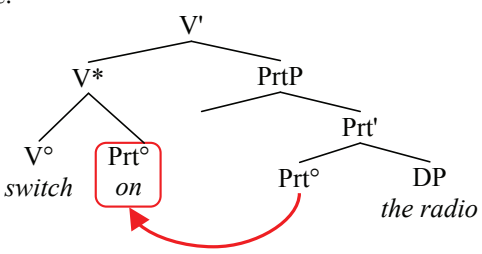

Idéen er at (19a) er den grundlæggende struktur, som dog aldrig vil nå overfladen: $\operatorname{Prt}^{\circ}$ kan ikke tilskrive kasus, og derfor vil DP'en ikke få en kasus, hvilket er fatalt for en DP.

Dette problem har to mulige løsninger (som også foreslået fx i Engels \& Vikner 2013: 227):

- $\quad$ En løsning er at flytte DP'en til specifikator-positionen i PrtP, (19b), hvor den kan tilskrives kasus direkte fra verbet, i en konfiguration 
der minder meget om ECM (exceptional case marking, diskuteret for dansk i Vikner 2014). Denne løsning resulterer i DP-Prt rækkefølgen i fx (5b): switch the radio on.

- $\quad$ Den anden løsning er at partiklen flyttes op og danner en $\mathrm{V}^{*}$, et komplekst verbum (hvor $\mathrm{V}^{*}$ er et nyt mellemniveau, dvs. en konstituent der er større end et $\mathrm{V}^{\circ}$, men mindre end et $\mathrm{V}^{\prime}$, som foreslået i bl.a. Haegeman \& Guéron 1999: 254 og Vikner 2005: 92). I dette tilfælde kan verbet nu tilskrive DP kasus (måske via partiklens spor i $\left.\mathrm{Prt}^{\circ}\right)$. Denne løsning resulterer i Prt-DP rækkefølgen i fx (5a): switch on the radio.

Både (19b) og (19c) er kompatible med de data der blev diskuteret ovenfor:

Hverken i (19b) eller i (19c) er Prt ${ }^{\circ}$ den del af $\mathrm{V}^{\circ}$, og derfor forventes det at $\mathrm{fx}$ switch on vil anbringe fleksionsendelsen efter switch og ikke efter switch on, (17) og (18), og det forventes ikke at switch on skal være en partikel som on.

Hverken i (19b) eller i (19c) er der en konstituent [Prt $\left.{ }^{\circ}+\mathrm{DP}\right]$, og derfor kan $\mathrm{Prt}^{\circ}+\mathrm{DP}$ ikke $h v$-flyttes, (6b), kløves, (7b), eller koordineres, (8b). Grunden til at man ikke kan modificere i (9b) er stadig at man ikke kan intervenere i det sammensatte verbum $V^{*}$. Verbum og partikel kan udelades sammen, (13b), idet de udgør en konstituent.

Engelsk og norsk har både (19b) og (19c), hvorimod svensk kun har (19b) og dansk (og færøsk) kun har (19c) (se fx Vikner 1987):1

\begin{tabular}{|c|c|c|c|}
\hline $\begin{array}{l}(20 a) \\
(20 b)\end{array}$ & $\begin{array}{l}\text { Peter threw } \\
\text { Peter threw the carp }\end{array}$ & out the carpet. & \\
\hline $\begin{array}{l}(21 \mathrm{a}) \\
(21 \mathrm{~b})\end{array}$ & $\begin{array}{l}\text { Petter kastet } \\
\text { Petter kastet teppet }\end{array}$ & $\begin{array}{l}\text { bort teppet. } \\
\text { bort. }\end{array}$ & \\
\hline $\begin{array}{l}(22 \mathrm{a}) \\
(22 \mathrm{~b})\end{array}$ & $\begin{array}{l}\text { Peter kastade } \\
\text { * Peter kastade mattan }\end{array}$ & $\underline{\text { bort }}$ mattan. & VENSK: KUN (19c) \\
\hline $\begin{array}{l}(23 a) \\
(23 b)\end{array}$ & $\begin{array}{l}\text { * Peter smed } \\
\text { Peter smed }\end{array}$ & $\begin{array}{l}\text { ud tæppet. } \\
\text { ud. }\end{array}$ & \\
\hline
\end{tabular}

1 Selvom engelsk (og norsk) har både (19b) og (19c), så gælder det kun for fulde DP'er som the radio i (5a,b) ovenfor. Hvis DP'en er et pronomen, så er det imidlertid kun (19c) der er mulig:

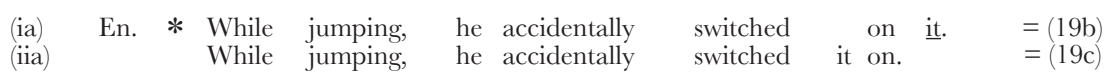


Som vist i Vikner (1987, 2007), Engels \& Vikner (2013, 2014), og mange andre steder, er mønstret i (21)-(23) helt det samme som mønstret for verber der er indlejret under det kausative verbum lade:

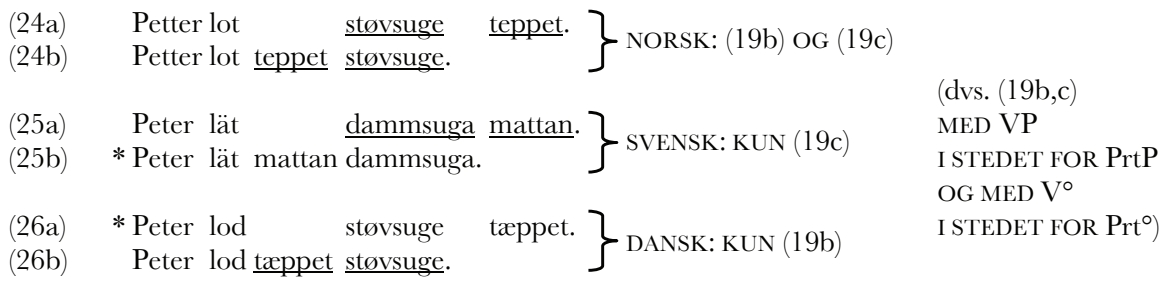

Idet jeg antager at dansk/norsk/svensk er SVO-sprog, følger det at (24b) og(26b) involverer flytning af DP'en - det ikke-acceptable alternativ er nemlig at (24a) og(25a) involverer flytning af infinitiven, og dette alternativ ville gøre norsk og svensk til OV-sprog.

Parallellerne mellem (21)-(23) og (24)-(26) fører derfor til antagelsen af at (23b) også involverer flytning af DP'en og ikke til antagelsen af at (23b) viser at danske partikler står efter deres komplement (hvilket heller ikke ville være kompatibelt med at tilskrive partikler og præpositioner den samme grundstruktur som i (14a) og (19a)).

\subsection{Verber og partikler $i$ de germanske SOV-sprog}

Hvis man følger den foreslåede analyse af verbalpartikler i de germanske SVO-sprog i (19) ovenfor, er spørgsmålet nu i hvor høj grad noget lignende gælder for verbalpartikler i de germanske SOV-sprog. Jeg vil foreslå at kun de rækkefølger som hænger sammen med $\mathrm{V}^{\circ}$ og dets komplement er anderledes (dvs. $V^{\circ} / \mathrm{V}^{*}$ står efter PrtP på fx tysk og ikke for PrtP som på fx engelsk og dansk), hvorimod rækkefølgen inden for $\mathrm{PP}$ og PrtP er den samme (dvs. $\mathrm{P}^{\circ}$ / $\mathrm{Prt}^{\circ}$ står før DP både på tysk og på engelsk/dansk).

(27a) Peter wird das Radio anmachen

TYSK

(27b) Pieter zal de radio aanzetten.

NEDERLANDSK

(27c) Pieter sal die radio aanskakel.

Peter vil radioen på-gøre (= 'Peter vil tænde for radioen')

AFRIKAANS

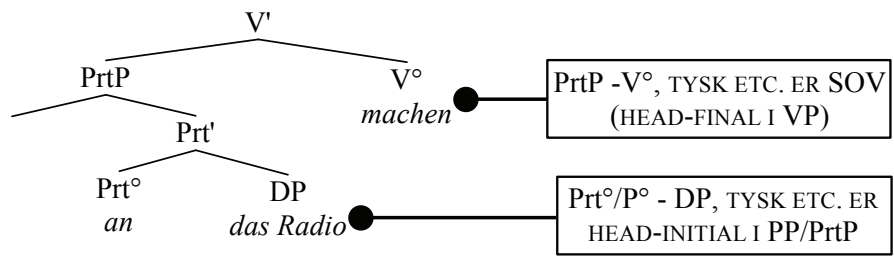


(28b)

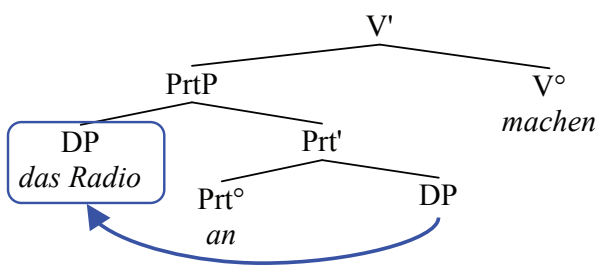

(28c)

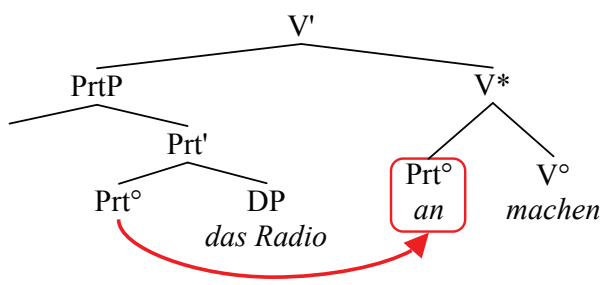

Med andre ord, hvad verbalpartikler angår, er der følgende forskelle og ligheder mellem SVO-sprog, (19), og SOV-sprog, (28):

- Den Løse partikels position (uanset om den er kerne i sin egen frase, PrtP, (19b) og (28b), eller den er søster til $\mathrm{V}^{\circ}$ og datter af $\mathrm{V}^{*},(19 \mathrm{c})$ og (28c)) er til venstre for verbet i OV-sprogene, (28), tysk anmachen, men til højre for verbet i VO-sprogene, (19), engelsk switch on. Dette er en syntaktisk egenskab (partiklen er aldrig en del af $\mathrm{V}^{\circ}$ ), og afhænger derfor af basisrækkefølgen mellem et verbum og dets komplement på det pågældende sprog (dvs. SOV/SVO-forskellen, tysk Ich habe das Buch gelesen vs. engelsk I have read the book og dansk Jeg har lest bogen; se fx Vikner 2007: 474-479).

- Den FASTE partikels position (den er altid både søster til en $\mathrm{V}^{\circ}$ og datter af en $\mathrm{V}^{\circ}$ ) er altid til venstre for verbet både på OV-sprogene, tysk verstehen, og på VO-sprogene, dansk forstå, engelsk understand (se også (1a), (2a) og (3a)). Dette er en morfologisk egenskab (partiklen er altid en del af $\mathrm{V}^{\circ}$ ), og afhænger derfor ikke af basisrækkefølgen mellem et verbum og dets komplement på det pågældende sprog. Dette er parallelt til fx de verbale flektionsmorfemers position, som også er en morfologisk egenskab, og som heller ikke varierer mellem germanske OV-sprog og VO-sprog.

Som (19b,c) udgør også (28b,c) to forskellige måder at tilskrive kasus til den DP som er komplement til den løse verbalpartikel, som vi så ved den engelske og skandinaviske variation DP-Prt ${ }^{\circ}$ vs. Prt $^{\circ}-\mathrm{DP}$ i (20)-(23) ovenfor. 
Spørgsmålet hvorfor der ikke er nogen variation i SOV-sprogene som svarer til variationen i (20)-(23) kan nu besvares: Uanset om et SOV-sprog kun anvender (28b), kun (28c), eller både (28b,c), er resultatet det samme, idet (28b,c) giver de samme forudsigelser m.h.t. rækkefølge (hvorimod (19b,c) giver forskellige forudsigelser m.h.t. rækkefølge).

Grunden er at (28b) er det samme som i SVO, dvs. DP'en flytter mod venstre, hvorimod (28c) er forskellig fra SVO, dvs. partiklen flytter mod højre. I SOV-sprogene har de to forskellige flytninger således det "samme" resultat (i hvert fald hvad rækkefølgen angår). Med andre ord, ved at gå ud fra at præpositioner og partikler er forskellige varianter af samme ordklasse, (19) og (28), får vi altså ikke blot reduceret antallet af ordklasser, men det giver os også et interessant bud på hvorfor den ordstillingsvariation mht. partikler der findes i dansk, norsk og svensk - som ellers ligner hinanden ret meget - ikke findes i de germanske OV-sprog (tysk/nederlandsk/afrikaans) - som ellers er ret forskellige. I afsnit 3 nedenfor vil jeg endvidere vise at hvis jiddisch antages at være SOV, vil en sådan analyse også kunne redegøre for hvorfor verbalpartiklerne i jiddisch opfører sig så forskelligt fra verbalpartiklerne i engelsk/skandinavisk og så parallelt med verbalpartiklerne i tysk/nederlandsk/afrikaans.

\subsection{Passiv med partikler og med prapositioner}

Idet DP'en tilskrives kasus fra verbet i begge versioner af partikel-konstruktionen, er det ikke overraskende at de begge kan passiveres:

(29a) [The radio $]_{1}$ was accidentally switched $\mathrm{t}_{1}$ on $\mathrm{t}_{1}$.

(29b) [The radio $]_{1}$ was accidentally [ switched on $\left.{ }_{2}\right] \quad t_{2} t_{1}$.

Det er mere overraskende at også præpositionskonstruktionen kan passiveres ("pseudo-passiv"):

Peter $_{1}$ will be laughed at $\mathrm{t}_{1}$.

Det der er mærkeligt ved den præpositionelle passiv, er at passiveringen forhindrer præpositionen at i at tilskrive kasus (og ikke verbet laugh), selvom passiveringen ændrer på verbets morfologi og ikke præpositionens morfologi.

En mulig analyse er at sige at grunden til at passivering af verbet laugh forhindrer præpositionen at $\mathrm{i}$ at tilskrive kasus er at præpositionen $\mathrm{i}$ en vis forstand er blevet en del af verbet. Hvis vi antager at også en præposition kan danne en $\mathrm{V}^{*}$ sammen med et verbum, ligesom partiklen gør i (19c), så kan 
vi redegøre for passiveringerne i (30) og (31). Hvis præpositionen er en del af et passiveret $\mathrm{V}^{*}$, så vil DP ikke få tilskrevet (akkusativ) kasus, og derfor vil den være parat til at flytte til subjektspositionen for at få tilskrevet (nominativ) kasus, som i (31).

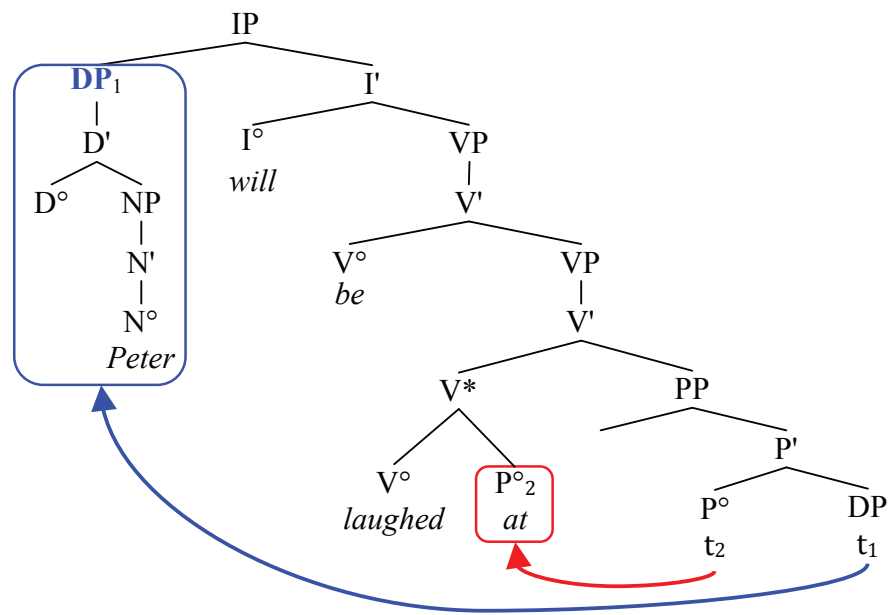

Dette giver en tværsproglig forudsigelse: Kun et af SVO-sprogene nævnt ovenfor, nemlig dansk, tillod ikke at partiklen blev en del af et $\mathrm{V}^{*}$, og derfor ville vi forvente at kun dansk ikke ville tillade eksempler på præpositionel passiv som (30), der jo involverer en parallel konstruktion med præpositionen som del af $\mathrm{V}^{*}$. Denne forudsigelse ser ud til at holde stik i det væsentlige²:

2 Som i Vikner (1995: 246) følger jeg her Herslund (1984: 70, fn 7) i antagelsen af at dansk ikke tillader præpositionel passiv, selvom dette ikke fuldt ud understøttes af data, som også påpeget af en anonym fagfællebedømmer. Laanemets \& Engdahl (2015: 232) finder således adskillige eksempler på præpositionel passiv dansk (i 0,8\% af deres sætninger med s-passiv og i 5,0\% af deres sætninger med blive-passiv). Disse tal er dog klart mindre end i både norsk (hhv. 3,8\% og 7,8\%) og svensk (hhv. 4,3\% og 13,3\%). Min analyse i dette afsnit kan således give et bud på hvorfor den andel af passiver som udgøres af præpositionelle passiver er klart mindre i dansk end i norsk, svensk og engelsk, men den har desværre ingen forklaring på hvorfor man overhovedet kan støde på præpositionel passiv i dansk.

Det skal også nævnes at Engdahl \& Laanemets (2015: 300) beregner præpositionel passiv til at være nogenlunde lige hyppig i dansk og svensk set $\mathrm{i}$ forhold til det totale antal ord i de respektive korpora (idet passiv generelt er mindre hyppig i svensk end i dansk), men jeg går altså her ud fra at det er forskellen i hyppigheden af præpositionelle passiver i forhold til totale antal passiver der er relevant. 
(32) He was laughed at.

(ENGELSK)

(33) Han ble ledd av.

(NORSK, Vinje 1987: 140)

(34) Skandalen skrattades åt.

(SVENSK, Platzack 1998: 122)

(35a) ?? Han blev grinet af.

(35b) ?? Skandalen blev grinet af.

(36a) Ham blev der grinet af.

(36b) Skandalen blev der grinet af.

I dette afsnit, afsnit 2, var fokus på løse verbalpartikler. Det er her der er partikelvariation, både mellem forskellige typer af SVO-sprog og mellem SVO-sprog og SOV-sprog, og det blev foreslået at det der er forskellen mellem SVO og SOV, er rækkefølgen inden i V' og i V* (dvs. den syntaktiske rækkefølge, hvilket involverer de løse partikler) men ikke rækkefølgen inden i $\mathrm{V}^{\circ}$ (dvs. den morfologiske rækkefølge, hvilket involverer de faste partikler).

\section{Løse vs. faste verbalpartikler}

I dette afsnit vil jeg forsøge at udvide analysen af verbalpartikler til at omfatte jiddisch. Inddragelsen af data med verbalpartikler underbygger det synspunkt at jiddisch er et OV-sprog som tysk og nederlandsk (som fremsat i Vikner 2001a,b, 2003, og mange andre steder), og ikke et VO-sprog som engelsk eller dansk.

\subsection{Lidt om jiddisch}

Mange lingvister er enige med Diesing (1997) i at jiddisch syntaktisk set svarer til tysk, dog med den vigtige forskel at jiddisch er SVO hvor tysk er SOV. Dette kan jeg ikke være enig i, for vi ved nemlig allerede hvordan et sprog ser ud der er ligesom tysk, men alligevel SVO: Dansk er et sådant sprog, men det er jiddisch ikke. 
Det er ikke ganske enkelt at finde ud af om jiddisch er SVO (som engelsk og dansk) eller SOV (som tysk), idet jiddisch ser ud til at have både SVO og SOV som mulige rækkefølger ${ }^{3}$ :

$$
\begin{aligned}
& \text { Ikh hob gezen Moyshn. } \\
& \text { Ikh hob Moyshn gezen. } \\
& \text { Jeg har (Moyshe) set (Moyshe) }
\end{aligned}
$$

(den Besten et al. 1986: 125, (43))

Hvis jiddisch var et SVO-sprog, så ville VO-rækkefølgen i (37a) ikke involvere flytning, hvorimod OV-rækkefølgen i (37b) ville involvere det man kalder scrambling:

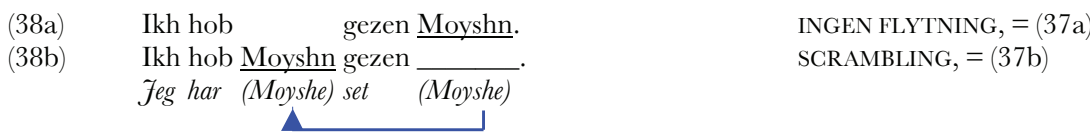

På den anden side, hvis jiddisch var et SOV-sprog, så ville OV-rækkefølgen i (37b) ikke involvere flytning, hvorimod VO-rækkefølgen i (37a) ville involvere det man kalder ekstraposition:

Ikh hob gezen Moyshn.

EKSTRAPOSITION,$=(37 \mathrm{a})$

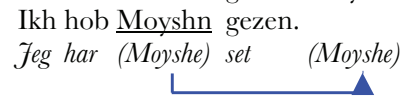

INGEN FLYTNING,$=(37 \mathrm{~b})$

Problemet er at man kan vise til at jiddisch faktisk har både ekstraposition og scrambling, hvilket igen betyder at vi må undersøge andre dele af syntaksen (fx verbalpartiklerne) for at finde ud af om jiddisch er SOV eller SVO.

Her er ganske kort evidensen for ekstraposition, hvilket er relevant for hvordan jeg kan sige at jiddisch er SOV og så alligevel have jiddische SVO-

3 Som påpeget af en anonym fagfællebedømmer kunne man også tænke sig at der ikke blot fandtes to forskellige typer germanske sprog (SOV: tysk/nederlandsk/afrikaans/frisisk/nedertysk og SVO: engelsk og de fem skandinaviske sprog) men også en tredje type som er variabel m.h.t. SOV/SVOdistinktionen. Ligesom tilfældet var med antallet af ordklasser tidligere, mener jeg også her at antagelsen af yderligere typer/elementer (i dette tilfælde antagelsen af en endnu en type germansk sprog) bør betragtes som en sidste udvej (jf. Ockhams ragekniv). Idet der som vist nedenfor eksisterer klar og uafhængig evidens for eksistensen af både scrambling og ekstraposition i jiddisch, er antagelsen af en ekstra sprogtype en udvej vi ikke behøver at benytte os af. 
eksempler som (44b) og (45b) nedenfor. Santorini (1993: 231, 243, n3) anfører at uanset om jiddisch er SOV eller SVO, så viser følgende eksempler at jiddisch har ekstraposition (altså en flytning til sætningens højre kant, i dette tilfælde uden anaforisk repræsentation):

(40a) Geveyntlekh hot ongehoybn esn der balebos.

Normalt har begyndt spise verten

(= 'Normalt var det værten der tog den første bid')

(40b) Durkh a kleyn shtetl hot gedarft durkhforn der keyser.

Gennem en lille by har måttet gennemkore kejseren

(= 'Kejseren blev nødt til at køre gennem en lille by')

(40c) Hot men derlangt oyfn tish fish.

Har man sat på bordet fisk

(= 'Fisk blev sat på bordet')

(Santorini 1993: 231, (1a), (2a,b))

Pointen er at subjektet normalt ville forekomme lige efter hot 'har' i både (40a) og (40b). Når subjektet alligevel står helt til sidst i (40a) og (40b), må det derfor være blevet flyttet helt ud i slutningen af sætningen (ekstraponeret), uanset om jiddisch måtte være SOV eller SVO. Hvad (40c) angår, så ville objektet fish 'fisk' normalt stå enten direkte før derlangt 'sat' hvis jiddisch var SOV, eller lige efter derlangt hvis jiddisch var SVO, så i begge tilfælde må det være blevet ekstraponeret her, hvor der står helt i slutningen af sætningen.

Som vist i Vikner (1995) forlanger jiddisch ikke at ekstraponerede konstituenter skal være særlig tunge, (43b), i modsætning til engelsk og skandinavisk som det ses i islandsk i (43a):

(41a) $\quad$... а раð hefur einhver borðað epli.

(ISLANDSK)

$\ldots$ as es hot emetser gegesn an epl.

(JIDDISH)

... at der har nogen spist et able

(42a) $\quad$... að pað hefur borðað petta epli einhver strákur frá Danmörku.

... at der har spist dette able en dreng fra Danmark

(ISLANDSK)

... az es hot gegesn an epl a yingl fun Danmark.

(JIDDISH)

... at der har spist et able en

dreng fra Danmark

(Vikner 1995: 200, (76), (77))

(43a) * ... аð раð hefur borðаð epli einhver.

(43b) ... az es hot gegesn an epl emetser.

(ISLANDSK)

... at der har spist et able nogen

(JIDDISH)

(Vikner 1995: 200, (75b,c)) 
(41) viser at både islandsk og jiddisch kan have transitive ekspletiv-konstruktioner (i modsætning til dansk og engelsk), (42) viser at både islandsk og jiddisch kan ekstraponere tunge subjekter i sådanne konstruktioner, og (43) viser at kun jiddisch tillader ekstraposition af et subjekt der ikke er tungt.

\subsection{Syntaktiske partikelforskelle mellem tysk, jiddisch og dansk}

Tysk, jiddisch og dansk er alle V2, dvs. i deklarative hovedsætninger skal det finitte verbum stå på andenpladsen i sætningen, uanset om førstepladsen optages af subjektet, (44), eller af en anden konstituent, (45):

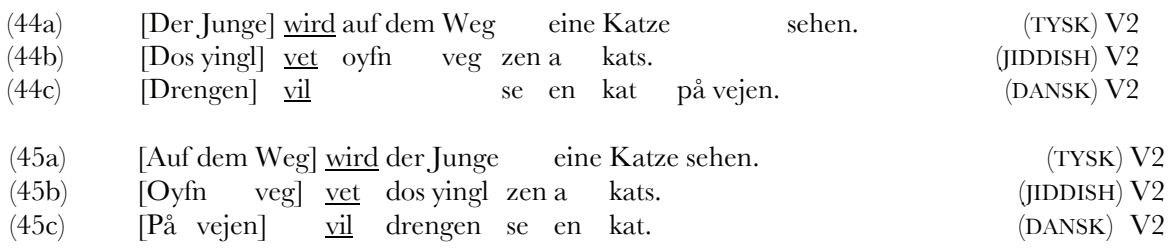

Det er derimod aldrig muligt at have det finitte verbum på tredjepladsen:

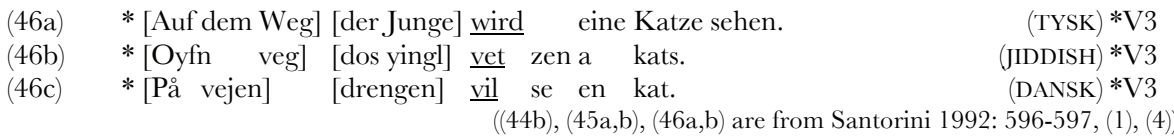

Som (45) viser, kan det finitte verbum flytte op foran subjektet, hvorimod dette ikke er muligt for et non-finit verbum, og det er denne forskel jeg vil udnytte nedenfor. På dansk kan forskellen mellem løse og faste partikler både ses når verbet undergår V2 og når det ikke gør. I en ikke-V2-kontekst står den løse partikel efter verbet men den faste partikel står før verbet:

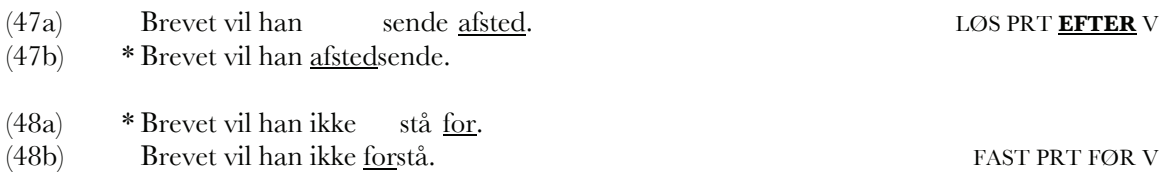

I en V2-kontekst bliver den løse partikel efterladt når det finitte verbum flytter, hvorimod den faste partikel flytter med som en del af verbet (det er jo derfor 
man taler om løse partikler vs. faste partikler, eller om løst sammensatte vs. fast sammensatte partikelverber):

$\begin{array}{lll}(49 \mathrm{a}) & \text { Brevet } \quad \text { sender han afsted. } & \text { LØS PRT BLIVER STÅENDE } \\ (49 \mathrm{~b}) & * \text { Brevet afstedsender han. } & \\ (50 \mathrm{a}) & * \text { Brevet står han ikke } \underline{\text { for. }} & \text { FAST PRT FLYTTER MED } \\ (50 \mathrm{~b}) & \text { Brevet forstår han ikke. }\end{array}$

På tysk og jiddisch derimod kan forskellen mellem løse og faste partikler kun ses når verbet undergår V2, og ikke når verbet ikke undergår V2. I en ikke-V2-kontekst står både den løse partikel og den faste partikel før verbet:

\begin{tabular}{|c|c|c|c|}
\hline (51a) & * Den Brief wird er $\quad$ schicken $\underline{\mathrm{ab}}$. & (TYSK) & \\
\hline$(51 b)$ & ?? Dem briv vet er & (JIDDISH) & \\
\hline$(51 c)$ & Den Brief wird er abschicken. & (TYSK) & LØS PRT FØR V \\
\hline$(51 d)$ & Dem briv vet er avekshikn. & (JIDDISH) & LØS PRT FØR V \\
\hline & Brevet vil han (afsted) sende & & \\
\hline$(52 \mathrm{a})$ & * Den Brief wird er nicht & (TYSK) & \\
\hline $2 b)$ & * Dem briv vet er nisht shteyn $\underline{\text { far. }}$. & (JIDDISH) & \\
\hline$(52 c)$ & Den Brief wird er nicht verstehen. & (TYSK) & FAST PRT FØR \\
\hline \multirow[t]{2}{*}{$(52 d)$} & Dem briv vet er nisht farshteyn. & (JIDDISH) & FAST PRT FØR \\
\hline & Brevet vil han ikke (for)stå (for) & & $\mathrm{V}$ \\
\hline
\end{tabular}

I en V2-kontekst bliver den løse partikel efterladt når det finitte verbum flytter, hvorimod den faste partikel flytter med som en del af verbet:

\begin{tabular}{|c|c|c|}
\hline (53a) & Den Brief & schickt er $\underline{\mathrm{ab}}$. \\
\hline $3 b)$ & Dem briv & er avek. \\
\hline (5c) & * Den Brief & abschickt er. \\
\hline & $\begin{array}{l}* \text { Dem briv } \\
\text { Brevet }\end{array}$ & $\begin{array}{ll}\text { avekshikt } & \text { er. } \\
(\text { afsted })_{\text {sender }} & \text { han (afsted) }\end{array}$ \\
\hline
\end{tabular}

(54a) * Den Brief steht er nicht ver.

(54b) * Dem briv shteyt er nisht far.

(54c) Den Brief versteht er nicht.

(54d) Dem briv farshteyt er nisht.

Brevet (for)står han ikke (for)

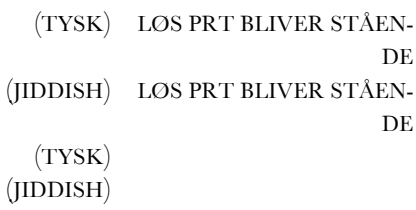

(TYSK) LØS PRT BLIVER STÅEN-

DE

(TYSK)

(JIDDISH)

((53b) er fra den Besten et al. 1986: 119, (20b))

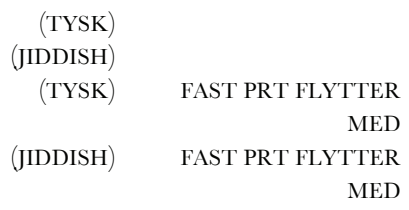


Dette mønster for både tysk og jiddisch er præcis det vi ville forvente under de antagelser vi gjorde i afsnit 2.3 ovenfor, nemlig at

- Den LøSE partikels position er syntaktisk bestemt, og afhænger derfor af basisrækkefølgen mellem et verbum og dets komplement på det pågældende sprog (dvs. SOV/SVO-forskellen, tysk Ich habe das Buch gelesen vs. dansk Jeg har lest bogen).

- Den FASTE partikels position er morfologisk bestemt og afhænger derfor ikke af basisrækkefølgen mellem et verbum og dets komplement på det pågældende sprog (den står altid til venstre for verbet både på OV-sprogene, tysk verstehen, og på VO-sprogene, dansk forstå

Det at jiddisch er helt ligesom tysk hvad verbalpartikler angår, ville således følge hvis jiddisch var SOV, men det ville være højst uventet hvis jiddisch var SVO. ${ }^{4}$

\section{Konklusion}

I afsnit 2 foreslog jeg at præpositioner og (løse) partikler har samme struktur:

(55) a.

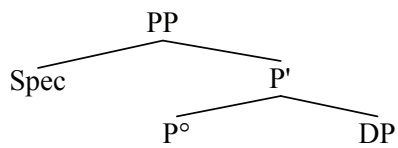

b.

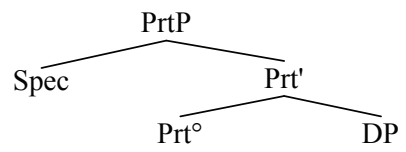

og at forskellen er at præpositioner tilskriver kasus til deres komplement, hvorimod partikler ikke gør det. Derfor vil den DP som er komplement til en partikel (fx the book i He threw out the book), ikke blive tilskrevet kasus. Dette problem har to mulige løsninger:

- $\quad$ ENTEN kan partiklen inkorporeres i verbet, som så (måske via sporet i $\mathrm{Prt}^{\circ}$ ) tilskriver kasus til komplementet. Resultat: He threw out the book,

4 For flere paralleller mellem tysk og jiddisch hvad verbalpartikler angår, se Vikner (2001b: 38-47). 
- $\quad$ ELLER DP'en kan flytte til PrtP-spec, hvor den kan tilskrives kasus direkte fra verbet (som i ECM-konstruktioner, Vikner 2014) -- resultat: He threw the book out.

SVO-sprogene varierer med hensyn til om de tillader den ene eller den anden eller begge løsninger, hvilket fører til den observerede partikelvariation mellem SVO-sprogene (og en beslægtet variation hvad angår præpositionel passiv). Dette billede blev udvidet til at omfatte de germanske SOV-sprog ved hjælp af antagelsen af at det der varierer mellem SVO og SOV, er :

- $\quad$ rækkefølgen mellem verber og løse partikler (dvs. den syntaktiske rækkefølge,

$$
\text { dansk } \neq \text { tysk, fx at købe } \underline{\text { ind }} \sim \text { einzukaufen }) \text {, men }
$$

- IKKE rækkefølgen mellem verber og faste partikler (dvs. den morfologiske rækkefølge,

$$
\text { dansk }=\text { tysk, fx at gennem } \underline{\text { hulle }} \sim z \text { u } \underline{\text { durch }} \underline{\underline{\text { löchern }}}) .
$$

Dette blev brugt til at forklare hvorfor den partikelvariation (Vikner 1987, Engels \& Vikner 2013, 2014 og mange andre) der findes i dansk, norsk og svensk - som ellers ligner hinanden ret meget - ikke findes i de germanske OV-sprog (tysk/nederlandsk/afrikaans) - som ellers er ret forskellige.

Afsnit 3 udvidede diskussionen til at omfatte både løse og faste partikler. Faste og løse partikler har forskellig struktur:

- Den LøSE partikels position er syntaktisk bestemt, og afhænger derfor af basisrækkefølgen mellem et verbum og dets komplement på det pågældende sprog (dvs. SOV/SVO-forskellen, tysk Ich habe das Buch gelesen vs. dansk feg har lest bogen).

- Den FASTE partikels position er morfologisk bestemt og afhænger derfor ikke af basisrækkefølgen mellem et verbum og dets komplement på det pågældende sprog (den står altid til venstre for verbet både på OV-sprogene, tysk verstehen, og på VO-sprogene, dansk forstå. 
Det at jiddisch er helt ligesom tysk hvad verbalpartikler angår, følger således af en analyse af jiddisch som SOV, men det ville være højst uventet hvis jiddisch var SVO. ${ }^{5}$

\section{Henvisninger}

den Besten, H. \& C. Moed-van Walraven (1986). The Syntax of Verbs in Yiddish, i H. Haider \& M. Prinzhorn (red.) Verb Second Phenomena in Germanic Languages, Dordrecht: Foris, 111-135.

Diesing, M. (1997). Yiddish VP Order and the Typology of Object Movement in Germanic, Natural Language and Linguistic Theory 15(2), 369-427.

Engdahl, E. \& A. Laanemets (2015). Prepositional passives in Danish, Norwegian and Swedish: A corpus study, Nordic Fournal of Linguistics 38(3), 285-337.

Engels, E. \& S. Vikner (2013). Scandinavian object shift, remnant VP-topicalisation, verb particles and causatives, Nordic Journal of Linguistics, 36(2), 219-244.

Engels, E. \& S. Vikner (2014). Scandinavian Object Shift and Optimality Theory. Basingstoke: Palgrave Macmillan.

Haegeman, L. \& J. Guéron (1999). English Grammar - A Generative Perspective. Oxford: Blackwell.

Haiden, M. (2005). Verb Particle Constructions, i H. van Riemsdijk \& M. Everaert (red.) The Syntax Companion V, Oxford: Blackwell, 344-375.

Herslund, M. (1984). Particles, Prefixes, and Preposition Stranding, i F. Sørensen \& L. Heltoft (red.) Topics in Danish Syntax. Nydanske Studier og Almen Kommunikationsteori (NyS) 14, 34-71.

Holmberg, A. (1999). Remarks on Holmberg's generalization, Studia Linguistica 53(1), 1-39.

5 Tak til en anonym fagfællebedømmer, til Maia Andréasson, Theresa Biberauer, Ken Ramshøj Christensen, Eva Engels, Lars Heltoft, Shin-Sook Kim, Henrik Jørgensen, Gereon Müller, Peter Sells, Michelle Sheehan, Carl Vikner, Johanna Wood, til redaktørerne af dette nummer af Ny Forskning $i$ Grammatik, til deltagerne i Grammatiknetværkets konference i Slagelse, oktober 2015, og til publikum ved forskellige foredrag og konferencer ved universiteterne i Berlin (Humboldt), Cambridge, Edinburgh, Konstanz, Lund, Marburg, Salzburg, Stuttgart, York, Aalborg og Aarhus. Denne forskning var en del af to forskningsprojekter ved Aarhus Universitet, finansieret af Forskningsrådet for Kultur og Kommunikation: Objektspositioner - komparativ syntaks i et tverteoretisk perspektiv og Ligheder og forskelle mellem setninger og nominalgrupper - sammenlignende syntaks på tvers af teoretiske tilgange. 
Laanemets, A. \& E. Engdahl (2015). Findes der præpositionspassiv i dansk?, i I. Schoonderbeek Hansen \& T.T. Hougaard (red.) 15. Møde om Udforskningen af Dansk Sprog (MUDS 15), Aarhus Universitet, Århus, 219-236. Tilgængelig online: http://muds.dk/rapporter/MUDS_15.pdf.

McIntyre, A. (2007). Particle Verbs and Argument Structure, Language and Linguistics Compass 1(4), 350-367.

McIntyre, A. (2013). English particle verbs as complex heads: Evidence from nominalization, i H. Härtl (red.) Interfaces of Morphology, Berlin: Akademie Verlag.

Platzack, C. (1998). Svenskans inre grammatik - det minimalistiska programmet. Lund: Studentlitteratur.

Santorini, B. (1992). Variation and change in Yiddish subordinate clause word order, Natural Language and Linguistic Theory 10, 595-640.

Santorini, B. (1993). Jiddish als gemischte OV/VO-Sprache, i W. Abraham \& J. Bayer (red.) Dialektsyntax (Linguistische Berichte, Sonderheft 5). Opladen: Westdeutscher Verlag, 230-245.

Schäfer, R. (2015). Einfiihrung in die grammatische Beschreibung des Deutschen. Berlin: Language Science Press. Tilgængelig online: http://langsci-press.org/ catalog/book/46.

Vikner, S. (1987). Case Assignment Differences between Danish and Swedish, i R. Allan \& M. Barnes (red.) Proceedings of the Seventh Conference of Scandinavian Studies in Great Britain, University College London, London, 262-281. Tilgængelig online: www.hum.au.dk/engelsk/engsv/papers/vikn87a.pdf. Vikner, S. (1995). Verb Movement and Expletive Subjects in the Germanic Languages. New York: Oxford University Press.

Vikner, S. (2001a). Predicative Adjective Agreement, i K. Adamzik \& H. Christen (red.) Sprachkontakt, Sprachvergleich, Sprachvariation: Festschrift für Gottfried Kolde, Niemeyer, Tübingen, 399-414. Tilgængelig online: www. hum.au.dk/engelsk/engsv/papers/vikn01b.pdf.

Vikner, S. (2001b). Verb Movement Variation in Germanic and Optimality Theory. "Habilitationsschrift", Universität Tübingen. Tilgængelig online: www. hum.au.dk/engelsk/engsv/papers/viknhabi.pdf.

Vikner, S. (2003). Null Objects under Coordination in Yiddish and Scandinavian, i L.-O. Delsing, et al. (red.) Grammar in Focus: Festschrift for Christer Platzack, vol. II. Inst f nordiska språk, Lunds Universitet, 365-375. Tilgængelig online: www.hum.au.dk/engelsk/engsv/papers/vikn03a.pdf.

Vikner, S. (2005). Immobile Complex Verbs in Germanic, Fournal of Comparative 
Germanic Linguistics 8(1-2), 83-115. Tilgængelig online: www.hum.au.dk/ engelsk/engsv/papers/vikn05b.pdf.

Vikner, S. (2007). Teoretisk og komparativ syntaks, i H. Jørgensen \& P. Widell (red.) Det bedre argument - Festskrift til Ole Togeby, 7. marts 2007. Århus: Wessel \& Huitfeldt, 469-480. Tilgængelig online: www.hum.au.dk/engelsk/ engsv/papers/vikn07a.pdf.

Vikner, S. (2014). Kan en konstituent være både subjekt og objekt på samme tid? - om indlejrede infinitivsætninger på dansk, i O. Togeby, S. Vikner \& H. Jørgensen (red.) Problemer og perspektiver $i$ dansk syntaks - med Kristian Mikkelsen som anledning. Odense: Universitets-Jubilæets danske Samfund/ Syddansk Universitetsforlag, 171-191. Tilgængelig online: www.hum. au.dk/engelsk/engsv/papers/vikn14a.pdf.

Vinje, F.-E. (1987). Moderne Norsk, Råd og regler for praktisk språkbruk. Oslo: Universitetsforlaget.

Williams, E. (1981). On the Notions Lexically Related and Head of a Word, Linguistic Inquiry 12(2), 31-43. 